\title{
Retrospective Evaluation of the Clinical Findings and Bone Mineral Densitometry Results of Children with Celiac Disease
}

\author{
Çölyak Hastalığı Olan Çocukların Klinik Bulguları ve Kemik Mineral \\ Dansitometri Sonuçlarının Retrospektif Olarak Değerlendirilmesi
}

\section{(D) Sezin Naiboğlu¹, (1 Zerrin Önal2, (1) Emrah Naiboğlu³}

${ }^{1}$ Esenyurt Necmi Kadıoğlu State Hospital, Clinic of Child Health and Diseases, İstanbul, Turkey

2İstanbul University Faculty of Medicine, Department of Pediatric Gastroenterology, İstanbul, Turkey

${ }^{3}$ University of Health Sciences Turkey, İstanbul Bakırköy Training and Research Hospital, Clinic of Child Health and Diseases, İstanbul, Turkey

\section{Abstract}

Objective: Children diagnosed with Celiac disease should be closely followed-up for osteoporosis that may develop. We aimed to evaluate the osteoporosis conditions through bone densitometry in patients with the diagnosis of celiac disease, who were given a strict gluten-free diet.

Method: The complaints at the time of admission, anthropometric data, laboratory findings at the time of admission, laboratory findings after gluten-free diet and bone densitometer results of 80 patients, who were followed-up at the pediatric gastroenterology outpatient clinic of our hospital and diagnosed with Celiac disease, were retrospectively investigated.

Results: The study was conducted between December 2015 and February 2016 with patients diagnosed with Celiac disease. The study was conducted with a total of 80 cases, 31 (38.8\%) boys and 49 (61.3\%) girls. The mean age of the cases was $10.01 \pm 4.75$ years. While the most common symptoms of the cases with gastrointestinal system findings were abdominal pain and diarrhea, the most common findings apart from the gastrointestinal system were growth and developmental delay and anemia. In our study, the frequency of osteoporosis was $14 \%$.

Conclusion: In our study, it is shown that the majority of children diagnosed with Celiac disease apply to the hospital with findings apart from the gastrointestinal system or asymptomatically. It is important to carefully question the non-gastrointestinal system findings of the disease. Requesting Bone Mineral Densitometry in the follow-up of Celiac disease is an important marker for diagnosis and increase in length of patients with osteoporosis.

Keywords: Celiac disease, child, osteoporosis

\section{Öz}

Amaç: Çölyak hastalığı tanısı almış çocuklar, gelişebilecek osteoporoz açısından yakın takipte olmalıdır. Çölyak tanısı almış ve sıkı glutensiz diyet başlanan çocukların kemik dansitometre ile osteoporoz durumları değerlendirilmesi amaçlanmıştır.

Yöntem: Hastanemiz çocuk gastroenteroloji polikliniğinden takipli Çölyak hastalığı tanısı olan 80 çocuğun başvuru yakınmaları, antropometrik verileri, başvuru sırasındaki laboratuvar bulguları ile glutensiz diyet sonrası bakılan laboratuvar bulguları ve kemik dansitometre sonuçları retrospektif olarak araştırıldı.

Bulgular: Çalışma Aralık 2015 ve Şubat 2016 tarihleri arasında hastanemizde Çölyak hastalığı tanılı hastalar ile yapılmıştır. Çalışma 31'i $(\% 38,7)$ erkek, 49'u $(\% 61,3)$ kız toplam 80 olgu ile yapılmıştır. Olguların yaş ortalaması $10,01 \pm 4,75$ yıldı. Gastrointestinal sistem bulguları olan olguların en sık semptomu karın ağrısı ve ishalken, gastrointestinal sistem dışı en sık görülen bulgular büyüme gelişme geriliği ve anemi olmuştur. Çalışmamızda, osteoporoz sıklığı \%14 olarak saptanmıştır.

Sonuç: Çalışmamızda Çölyak hastalığı tanısı almış çocukların çoğunluğunun gastrointestinal sistem dışı bulgularla hastaneye başvurdukları veya asemptomatik oldukları gösterilmektedir. Hastalığın gastrointestinal sistem dışı bulgularının dikkatle sorgulanması önemlidir. Çölyak hastalığı takibinde Kemik Mineral Dansitometre istenmesi osteoporoz olan hastaların tanı alması ve boy uzaması açısından önemli bir belirteçtir.

Anahtar kelimeler: Çocuk, Çölyak hastalığı, osteoporozis

Address for Correspondence: Sezin Naiboğlu, Esenyurt Necmi Kadıoğlu State Hospital, Clinic of Child Health and Diseases, i̇stanbul, Turkey E-mail: sezin_ctnol@hotmail.com ORCID: orcid.org/0000-0002-9593-1136 Received: 22.04.2020 Accepted: 12.07.2020

Cite this article as: Naiboğlu S, Önal Z, Naiboğlu E. Retrospective Evaluation of the Clinical Findings and Bone Mineral Densitometry Results of Children with Celiac Disease. Bagcilar Med Bull 2020;5(3):88-93

${ }^{\odot}$ Copyright 2020 by the Health Sciences University Turkey, Bagcilar Training and Research Hospital Bagcilar Medical Bulletin published by Galenos Publishing House. 


\section{Introduction}

Celiac disease (CD, gluten enteropathy) is a proximal small bowel disease developing as permanent intolerance against gluten in wheat, and gluten-like and other grain proteins in grains such as barley, rye, oats in genetically susceptible people. Gluten sensitive enteropathy is also called celiac "sprue" (non-tropical sprue) (1). Although the disease is known as an enteropathy, it has become a disease of every system with the findings of the extra-gastrointestinal system that were revealed in recent years.

Gluten is a protein found in wheat and other grains, and it causes the disease with its prolamin part that can be dissolved in alcohol. Peptide sequences rich in glutamine and proline in the gliadin are responsible for gluten toxicity $(2,3)$. It is known that mucosal damage occurs due to the overstimulation of cellular and humoral immunity and interferon gamma produced by gluten-specific $\mathrm{T}$ cells is activated in gluten enteropathy (4).

Most patients have an atypical or silent clinical course (1-5). The disease is diagnosed with biopsy findings of intraepithelial lymphocyte increase, crypt hyperplasia and villus atrophy in the small intestine mucosa (5). It is important to detect antigliadin antibody, anti-tissue transglutaminase antibody, and/or anti-endomysium antibody (IgA-EmA) in the first step of diagnosis. After the diagnosis, the antibody levels are expected to decrease or disappear completely with a strict gluten-free diet. This is important for follow-up.

The clinical course of $\mathrm{CD}$ can be quite different and variable. The gastrointestinal (GIS) tract and non-GIS symptoms of $\mathrm{CD}$ are mostly due to absorption disorder developed in the proximal small intestine. Fatty, dulllooking, more frequent and abundant stool is the most important finding of this pathology. However, typical symptoms such as diarrhea and abdominal distention in infants are becoming less common. In addition, even patients with very mild findings can be diagnosed with serological tests. According to current data, it should be noted that there are 5-7 undiagnosed celiac patients for every patient diagnosed (6). The detection of large number of asymptomatic cases from symptomatic cases through community screening has caused the disease to be compared to the "iceberg" model (7).

In this study, the admission complaints, laboratory data at the time of diagnosis and serological test results of the patients, who were followed up in pediatric gastroenterology outpatient clinic, were evaluated. Additionally, laboratory results of the patients in the period after the diet and bone densitometry results in terms of osteoporosis were evaluated.

\section{Materials and Methods}

This retrospective study was conducted at University of Health Sciences Turkey, Bakırköy Dr. Sadi Konuk Training and Research Hospital, in the Pediatric Gastroenterology Outpatient Clinic, with Celiac patients. The study was approved by the Ethics Committee of University of Health Sciences Turkey, Bakırköy Dr. Sadi Konuk Training and Research Hospital on 23.02.15 with decision no: 2015/04/02. In the study, patients' complaints upon admission to the Pediatric Gastroenterology Outpatient Clinic, clinical findings, laboratory data and bone densitometer values were scanned from the patients' files. The study was conducted between December 2015 and February 2016 and the files of 80 patients were examined retrospectively. Patients who were not examined in our hospital and had no results in their files were excluded from the study. The waiver of consent was not required due to the retrospective design of the study.

Anthropometric measurements of patients were examined with the Endo C program. Standard deviation score (SDS) calculations of patients' height, weight and body mass index values were obtained. Tests of all patient were performed in the same laboratory and at similar times. Bone densitometry measurements of patients $(n=55)$ were performed on the same device.

Patients' bone densitometry (BMD) measurements were obtained considering age. The results of the patients were adjusted according to patients' age and ethnicity. Since the $\mathrm{z}$-score cannot be obtained in patients who are 4 years old and under, patients in this age group were not included in the bone densitometer measurement. Twenty five patients were under the age of 4 years so we had 55 patients' BMD results.

\section{Statistical Analysis}

Statistical analysis was conducted using NCSS (Number Cruncher Statistical System) 2007 Statistical Software (Utah, USA) package program. In addition to descriptive statistical methods (mean \pm standard deviation) used to evaluate the data, the study utilized in dependent t-test to compare binary groups and the chi-square test to compare qualitative data. The results were evaluated according to significance level of $\mathrm{p}<0.05$. 


\section{Results}

Eighty patients aged between 1 and 18 years were included in the study; 31 (38.7\%) were boys and 49 (61.3\%) were girls. The mean age of patients was $10.01 \pm 4.75$ years. Complaints of patients began between 20 months and 16 years with an average of $6.33 \pm 4.63$ years.

The patients were divided into three groups according to their symptoms. While $45 \%$ of the cases had non-GIS symptoms, $13.75 \%$ of the cases were asymptomatic. The most common non-GIS findings in patients were growth and developmental retardation and anemia. In the cases with GIS findings (\%41.25), 11.25\% had abdominal pain and $7.5 \%$ had diarrhea. Other admission complaints and findings were $6.25 \%$ constipation, $6.25 \%$ abdominal swelling, $6.25 \%$ vomiting, and $3.75 \%$ reflux (Table 1 ).

In the follow-up of CD, the height SDS value in patients who had become anti-endomysium antibody negative after gluten-free diet was found to be significantly higher than patients who had not yet become celiac antibodies negative (Table 2). When the results of bone densitometry according to the IgA-EmA negativity of the patients were examined, 6 patients with osteoporosis were IgA-EmA negative and 2 patients were IgA-EmA positive (Table 2).

Table 1. Distributions of the complaints

\section{n $\%$}

\begin{tabular}{lll}
\hline - GIS symptoms & & \\
Constipation & 5 & 6.25 \\
Vomiting & 5 & 6.25 \\
Abdominal pain & 9 & 11.25 \\
Abdominal swelling & 5 & 6.25 \\
Diarrhea & 6 & 7.5 \\
Reflux complaints & 3 & 3.75 \\
Total & 33 & 41.25 \\
- Non-GIS symptoms & & \\
Growth and developmental retardation & 21 & 26.25 \\
Iron deficiency anemia & 11 & 13.75 \\
Hypertransaminasemia & 3 & 3.75 \\
Cholelithiasis & 1 & 1.25 \\
Total & 36 & 45 \\
- Asymptomatic patients & \multicolumn{2}{|l}{} \\
Celiac in sister/brother & 3 & 3.75 \\
Type 1 DM & 6 & 7.5 \\
Chronic disease & 2 & 2.5 \\
Total & 11 & 13.75 \\
\hline
\end{tabular}

GIS: Gastrointestinal, DM: Diabetes Mellitus
Calcium, phosphorus, alkaline phosphate bone isoenzyme and Parathormone (PTH) measurements of the cases (included only 55 patients who have BMD results) were not statistically significant according to the bone densitometry status (Table 3).

The frequency of osteoporosis was $14 \% \quad(n=8)$ of the study (55 patients had BMD results). $87 \%$ of patients with osteoporosis had vitamin D deficiency. While there was no correlation between Alkaline Phosphate Bone Isoenzyme increase and vitamin D deficiency, there was a significant relationship between Alkaline Phosphate Bone Isoenzyme and PTH. The weight SDS and height SDS values of patients with normal bone densitometry were significantly higher than those whose bone densitometry revealed osteopenia and osteoporosis (Table 4).

\section{Discussion}

Celiak Disease is an enteropathy triggered by the consumption of gluten-containing wheat, barley, rye and oat foods and formed by an immune mechanism. The disease is more common in women than in men. In our study, including $38.7 \%$ boys and $61.3 \%$ girls, the disease was found to be more common in girls. According to our study, the average age of the onset of thebcomplaints in patients was $6.33 \pm 4.63$ years, which was attributed to the widespread screening and diagnosis of atypical patients.

Celiac patients can have GIS findings or non-GIS findings or they can be completely asymptomatic. Celiac patients are referred to hospitals with GIS related findings such as diarrhea, fatty stool, abdominal pain, abdominal distention and constipation due to malabsorption. However, almost half of the patients are referred to hospitals with extraintestinal and atypical findings such as anemia, osteoporosis, short stature, growth and developmental retardation, hypertransaminasemia, and neurological problems (8). In a study conducted by Akay Hacı et al. (9) in $2015,58.3 \%$ of the cases had non-GIS findings. Similarly, in our study, $41.25 \%$ of the cases presented with gastrointestinal findings and $45 \%$ with non-gastrointestinal findings, while $13.75 \%$ of the cases were found to be asymptomatic. Ertekin et al. (10) and other studies found that the most common complaint was the developmental reterdation. The most frequent complaint in our study was growth retardation (26.25\%) and respectively iron deficiency anemia (13.75\%) and abdominal pain (11.25\%).

In asymptomatic patients presenting with atypical symptoms, iron deficiency anemia, high liver enzyme 
Table 2. Evaluation of bone densitometry results about IgA-EmA negative status

\begin{tabular}{|c|c|c|c|c|}
\hline \multirow{2}{*}{ After diet } & & \multicolumn{2}{|l|}{ IgA-EmA status } & \multirow{2}{*}{$\mathbf{p}$} \\
\hline & & Currently (+) $(n=43)$ & Currently (-) (n=37) & \\
\hline \multirow{2}{*}{ Weight SDS } & $M \pm S D$ & $-1.03 \pm 1.24$ & $-0.74 \pm 1.39$ & \multirow{2}{*}{${ }^{c} 0.324$} \\
\hline & Min-max (Median) & $-4-1.10(-1)$ & $-3.9-1.8(-0.60)$ & \\
\hline \multirow{2}{*}{ Height SDS } & $M \pm S D$ & $-1.33 \pm 1.21$ & $-0.72 \pm 1.25$ & \multirow{2}{*}{${ }^{c} 0.031^{*}$} \\
\hline & Min-max (Median) & $-3.6-1(-1.3)$ & $-3.5-2(-0.9)$ & \\
\hline \multirow{2}{*}{ BMI SDS } & $M \pm S D$ & $-0.20 \pm 1.01$ & $-0.37 \pm 1.55$ & \multirow{2}{*}{ c0.569 } \\
\hline & Min-max (Median) & $-1.8-1.9(-0.20)$ & $-5 .-2.3(-0.20)$ & \\
\hline & & n (\%) & n (\%) & \\
\hline \multirow{3}{*}{ Bone densitometry } & Normal & $13(46.4)$ & $15(55.6)$ & \multirow{3}{*}{ f 0.114} \\
\hline & Osteopenia & $13(46.3)$ & $6(22.2)$ & \\
\hline & Osteoporosis & $2(7.1)$ & $6(22.2)$ & \\
\hline
\end{tabular}

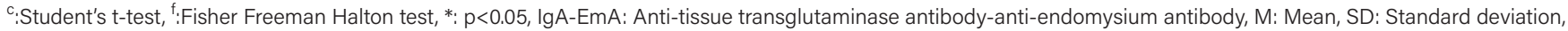
Min: Minimum, Max: Maximum, SDS: Standard deviation score, BMI: Body mass index

\section{Table 3. Evaluation of laboratory results according to bone densitometer results}

\begin{tabular}{|c|c|c|c|c|c|}
\hline & & \multicolumn{3}{|c|}{ Bone densitometry results } & \multirow[b]{2}{*}{ p } \\
\hline & & $\begin{array}{l}\text { Normal } \\
(n=28)\end{array}$ & $\begin{array}{l}\text { Osteopenia } \\
(n=19)\end{array}$ & $\begin{array}{l}\text { Osteoporosis } \\
(n=8)\end{array}$ & \\
\hline \multirow{2}{*}{ Calcium (mg/dL) } & $M \pm S D$ & $10.21 \pm 1.86$ & $9.68 \pm 0.60$ & $10.06 \pm 0.81$ & \multirow{2}{*}{90.547} \\
\hline & Min-max (Median) & $8.1-19(9.8)$ & $8-10.4(9.85)$ & $9.1-11.2(10.1)$ & \\
\hline \multirow{2}{*}{ Phosphorus (mg/dL) } & $M \pm S D$ & $4.53 \pm 0.49$ & $4.41 \pm 0.74$ & $4.31 \pm 0.79$ & \multirow{2}{*}{90.276} \\
\hline & Min-max (Median) & $3.4-5.1(4.65)$ & $3.2-6.5(4.2)$ & $3.4-5.8(4.2)$ & \\
\hline \multirow{2}{*}{$\begin{array}{l}\text { Alkaline phosphate } \\
\text { (bone isoenzyme) (U/L) }\end{array}$} & $M \pm S D$ & $131.68 \pm 52.49$ & $98.58 \pm 49.69$ & $126.88 \pm 45.19$ & \multirow{2}{*}{90.205} \\
\hline & Min-max (Median) & $39-258(116.5)$ & $16-182(105)$ & $60-179(135.5)$ & \\
\hline \multirow[t]{2}{*}{ PTH (pg/mL) } & $M \pm S D$ & $37.08 \pm 12.44$ & $39.39 \pm 15.44$ & $53.90 \pm 30.30$ & \multirow{2}{*}{ g0.326 } \\
\hline & Min-max (Median) & $17-68(33)$ & $16-81(35.5)$ & $23-116(46.5)$ & \\
\hline \multirow{2}{*}{ Vitamin D (ng/mL) } & $M \pm S D$ & $25.58 \pm 23.34$ & $27.26 \pm 21.25$ & $19.99 \pm 10.22$ & \multirow{2}{*}{ g0.755 } \\
\hline & Min-max (Median) & $3-128(21)$ & $3.7-98(22.7)$ & 7-39 (19.7) & \\
\hline
\end{tabular}

g:Kruskal-Wallis test, M: Mean, SD: Standard deviaton, Min: Minimum, Max: Maximum, PTH: Parathormone

Table 4. Evaluation of weight SDS, height SDS, BMD SDS results according to bone densitometer results

\begin{tabular}{lllll} 
& \multicolumn{2}{l}{ Bone densitometry results } \\
\cline { 3 - 4 } Weight SDS & Normal $(\mathbf{n = 2 8})$ & Osteopenia $(\mathbf{n = 1 9 )}$ & Osteoporosis $(\mathbf{n = 8})$ \\
\hline \multirow{2}{*}{ Height SDS } & M \pm SD & $-0.39 \pm 0.89$ & $-1.23 \pm 0.86$ & $-1.53 \pm 1.40$ \\
& $M \pm$ SD & $-2.1-1.1(-0.45)$ & $-2.6-0.5(-1.25)$ & $-3.9--0.3(-1)$ \\
\multirow{2}{*}{ BMD SDS } & Min-max (Median) & $-0.40 \pm 1.09$ & $-1.51 \pm 1.04$ & $-1.56 \pm 0.95$ \\
& $M \pm$ SD & $-2.1-2(-0.35)$ & $-3.6-0.6(-1.3)$ & $-3.1--0.6(-1.25)$ \\
\hline
\end{tabular}

M: Mean, SD: Standard deviation, SDS: Standard deviation score, BMD: Bone densitometry, Min: Minimum, Max: Maximum

levels, cholelithiasis cases, and CD should be kept in mind in the differential diagnosis and necessary serological tests should be requested (11).

Development retardation and short stature in CD are thought to originate from nutritional deficiencies, low serum somatomedin activity, and defects in growth hormone release (12). Patients catch up to their peers by gaining height and weight in a short time with a strict gluten-free diet. For this reason, CD should definitely be considered in differential diagnosis when approaching a short child. It is important to suspect CD and make an 
early diagnosis for the growth and development of patients. According to our study, a strict gluten-free diet created a significant difference in the height of the patients with $\mathrm{CD}$ and IgA-EmA negativity was found to be a significant parameter in terms of height growth in Celiac patients.

Although it was said that there was an improvement in the bone mineral densitometer in the first year after a glutenfree diet, Margoni et al. (13) found lower bone densitometry even in the second year of the gluten-free diet. Although Kuloğlu et al. (14) and other pediatric studies found that there was a slight increase in the first year after gluten-free diet, it was revealed that Celiac patients might have lower bone densitometry than normal individuals despite normal diet and negative antibodies.

In untreated patients, the BMD was found to be lower than in normal individuals and rapidly returned to normal with a strict gluten-free diet therapy. In the study conducted by Kondolot et al. (15) in 2009, $22 \%$ of 41 celiac patients who had BMD measurements had osteopenia, $12.2 \%$ had osteoporosis, and rickets were found in two patients (14.3\%). In the study of Tau et al. (16) on 24 celiac patients aged 1 to 11 years, BMD measurement of the patients diagnosed with $z$-score values was found to be quite low. In this study, $17 \%$ had osteoporosis (Z score was below -2 standard deviation). Zanchi et al. (17) stated that osteopenia was detected at the rate of $\% 18$ in dual energy X-ray absoptiometry screening in 54 celiac children without treatment. Similarly, in our study, osteopenia was found in $34 \%$ of cases and osteoporosis was found in $14 \%$.

The most important point here is that it is known that patients diagnosed with $\mathrm{CD}$ are more at risk in terms of vitamin $\mathrm{D}$ deficiency compared to the normal population and vitamin D level and BMD measurement of these patients should be followed closely.

Scotta et al. (18) showed that patients with prepubertal diagnosis might have a significant improvement in bone mineral densitometry. However, the diagnosis in the postpubertal period has been proven by studies to have no significant effect on bone mineral densitometry. Turner et al. (19) did not find a significant difference in BMD in asymptomatic and symptomatic patients.

In $\mathrm{CD}$, the only effective treatment of which is a life-long gluten-free diet, no negative effects of the gluten-free diet were encountered in the long term (20). Morbidity and mortality increase significantly in patients that are not on diet, GIS symptoms improve with gluten-free diet, height and weight reach the expected level, hematological and biochemical parameters come to normal limits. In asymptomatic Celiac patients, feeling of physical and psychological well-being has been reported with glutenfree diet therapy. In addition, according to the studies conducted, an improvement in bone mineralization was detected in patients with prepubertal diagnosis. Patients who follow a strict gluten-free diet or have limited gluten intake may have osteoporosis in the years to come, as well as osteopenic or normal.

Obviously, our study has strengths and weaknesses. The limitations of our study arise mainly from the small number of patients and the variation in final follow-up determination time-points. In spite of these limitations, the results of this study strongly suggest that diagnosis and treatment are made before puberty, thereby preventing osteopenia in adult life. In addition, daily calcium and protein intake are not the same in every child with $\mathrm{CD}$.

Studies have not yet been sufficient to determine the minimal amount of gluten that will cause osteoporosis. The mechanism of vitamin D deficiency causing osteoporosis, increased PTH levels, decreased intestinal calcium absorption and other parameters on bone mechanism have not been fully clarified.

\section{Conclusion}

In summary, our findings and other studies suggest that it is important to carefully question the non-GIS findings of the disease, such as growth retardation, anemia, shortness, and osteoporosis. In cases where CD is suspected, complaints at admission must be taken into consideration. Early diagnosis in CD prevents serious complications such as osteoporosis. If timely recognized and treated, the disease prognosis is good.

\section{Ethics}

Ethics Committee Approval: The study was approved by the Ethics Committee of University of Health Sciences Turkey, Bakırköy Dr. Sadi Konuk Training and Research Hospital on 23.02.15 with decision no: 2015/04/02.

Informed Consent: The waiver of consent was not required due to the retrospective design of the study.

Peer-review: Externally peer-reviewed.

\section{Authorship Contributions}

Concept: Z.Ö., Design: S.N., Data Collection or Processing: E.N., Analysis or Interpretation: S.N., Literature Search: Z.Ö., Writing: S.N. 
Conflict of Interest: No conflict of interest was declared by the authors.

Financial Disclosure: The authors declared that this study has received no financial support.

\section{References}

1. Maki M, Lohi O. Celiac Disease. In: Walker WA, Goulet O, Kleinman RE, Sherman PM, Shneider BL, Sanderson IR (eds). Pediatric Gastrointestinal Disease. 4th ed. Ontario: B.C. Decker, 2004:93243.

2. Nilsen EM, Jahnsen FL, Lundin KE, Johansen FE, Fausa O, Sollid LM, et al. Gluten induces an intestinal cytokine response strongly dominated by interferon gamma in patients with celiak disease. Gastroenterology 1998;115(3):551-563.

3. Przemioslo RT, Lundin KE, Sollid LM, Nelufer J, Ciclitira PJ. Histological changes in small bowel mucosa induced by gliadin sensitive T lymphocytes can be blocked by anti-interferon gamma antibody. Gut 1995;36:874-879.

4. Molberg O, Mnadam SN, Körner R, Quarsten H, Kristiansen C, Madsen L, et al. Tissue transglutaminase selectively modifies gliadin peptides that are recognised by gut derived cells in coeliac disease. Nat Med 1998;4(6):713-717.

5. Hill ID, Bhatnagar S, Cameron DJS, De Rosa S, Maki M, Russell G, et al. Celiac Disease: Working Group Report of the First World Congress of Pediatric Gastroenterology, Hepatology and Nutrition. J Pediatr Gastroenterol Nutr 2002;35(Suppl 2):578-588.

6. Högberg L, Magnusson FK, Grodzinsky E, Stenhammar L. Familial prevalence of coeliac disease: a Twenty- Year Follow-up Study. Scand J Gastroenterol 2003;38(1):61-65.

7. Fasano A, Catassi C. Coeliac disease in children. Best Pract Res Clin Gastroenterol 2005;19:467-478.

8. Husby S, Koletzko S, Korponay-Szabó IR, Mearin ML, Phillips A, Shamir R, et al. European Society for Pediatric Gastroenterology, Hepatology, and Nutrition. European Society for Pediatric Gastroenterology, Hepatology, and Nutrition guidelines for the diagnosis of coeliac disease. J Pediatr Gastroenterol Nutr 2012;54(1):136-160.
9. Akay Hacı I, Kuyum P, Çakar S, Işı İ, Arslan N. Presenting symptoms of pediatric patients with celiac disease. Abant Med J2015;4(2):146150.

10. Ertekin V, Selimoglu MA, Altinkaynak S. Celiac disease in childhood: evaluation of 140 patients. Eurasian J Med 2009;41(3):154-157.

11. Abaci A, Esen I, Ünüvar T, Arslan N, Bober E. Two cases presenting with pubertal delay and diagnosed as Celiac disease. Clin Pediatr (Phila) 2008;47(6):607-609.

12. Lecornu M, David L, Francois R. Low serum somatomedinactivity in celiac disease. Helv Pediatr Acta 1978;33(6):509-516.

13. Margoni D, Chouliaris G, Duscas G, VoskakiI, Voutsas N, Papadapoulou A, et al. Bone Health in Children with Celiac Disease Assesedby Dual-X-Ray Absorptiometry: Effect of Gluten Free Diet and Predictive Value of Serum Biochemical Indices. Journal Pediatr Gastroenterol Nutr 2012;54(5):680-684.

14. Kuloğlu Z, Kırsaçlıoğlu C, Kansu A, Ensari A, Girgin N. Açıklanamayan Transaminaz Yüksekliği ve Atipik Çölyak Hastalığı: Olgu Sunumu. Türkiye Çocuk Hast Derg 2008;2(2):33-38.

15. Kondolot M, Demirçeken F, Ertan Ü. 52 Vaka İle Türk Çocuklarında Çölyak Hastalığı. Türkiye Çocuk Hast Derg 2009;3(1):10-17.

16. Tau C, Mautalen C, De Rosa S, Roca A, Valenzuela X. Bone mineral density in children with celiac disease. Effect of a Gluten-free diet. Eur J Clin Nutr 2006;60(3):358-363.

17. Zanchi C, Di Leo G, Ronfani L, Martelossi S, Not T, Ventura A. Bone metabolism in celiac disease. J Pediatr 2008;153(2):262-265.

18. Scotta MS, Salvatore S, Salvatoni A, De Amici M, Ghiringhelli D, BrogginiM, et al. Bone mineralization and body composition in young patients with celiac disease. Am J Gastroenterol 1997;92(8):1331-1334.

19. Turner J, Pellerin G, Mager D. Prevalence of metabolic bone disease in children with celiac disease is independent of symptoms at diagnosis. J Pediatr Gastroenterol Nutr 2009;49(5):589-593.

20. Green PH. The many faces of celiac disease: clinical presentation of celiac disease in the adult population. Gastroenterology 2005;128(4 Suppl 1):S74-78. 